\title{
OPTIMALISASI SUMBERDAYA LAHAN UNTUK BUDIDAYA TAMBAK DI KABUPATEN LUWU UTARA PROVINSI SULAWESI SELATAN
}

\author{
Erna Ratnawati \\ Balai Penelitian dan Pengembangan Budidaya Air Payau \\ Jl. Makmur Dg. Sitakka No. 129, Maros 90512, Sulawesi Selatan \\ E-mail: ernaratnawati60@yahoo.co.id
}

\section{ABSTRAK}

Kabupaten Luwu Utara (Lutra) memiliki lahan potensial untuk tambak dan perubahan luas lahan tambak yang cukup besar, tetapi produktivitas tambak untuk budidaya udang dan ikan yang rendah. Oleh karena itu, Balai Penelitian dan Pengembangan Budidaya Air Payau, Maros telah melakukan serangkaian penelitian yang bertujuan untuk mengetahui luas potensi lahan, kesesuaian lahan, dan kebutuhan faktor lingkungan untuk budidaya rumput laut di tambak Kabupaten Lutra yang hasilnya dirangkum dalam makalah ini. Tambak di Kabupaten Lutra meningkat dari 4.938,84 ha pada tahun 2002 menjadi 7.838,94 ha pada tahun 2005. Potensi lahan tambak di Kabupaten Lutra mencapai $11.299,00$ ha yang terdiri atas lahan tambak yang ada seluas 7.838,94 ha dan potensial lahan tambak seluas 3.460,06 ha. Dari luas potensi lahan tambak di Kabupaten Lutra, ternyata 3.527,3 ha tergolong sangat sesuai (kelas S1); 490,9 ha tergolong cukup sesuai (kelas S2); dan 7.280,8 ha tergolong kurang sesuai (kelas S3). Produksi rumput laut yang tinggi dapat diperoleh di tambak Kabupaten Lutra pada tanah dengan $\mathrm{pH}_{\mathrm{F}}$ lebih besar 6,5; $\mathrm{pH}_{\mathrm{FOX}}$ lebih besar 4,0; $\mathrm{pH}_{\mathrm{F}}-\mathrm{pH}_{\mathrm{FOX}}$ kurang dari 2,5; dan $S_{\text {POS }}$ kurang dari $1,00 \%$. Kandungan Fe tanah yang melebihi $5.000 \mathrm{mg} / \mathrm{L}$ dan $\mathrm{Al}$ yang melebihi 490 $\mathrm{mg} / \mathrm{L}$ menyebabkan penurunan produksi rumput laut. Peningkatan kandungan $\mathrm{PO}_{4}$ tanah lebih besar dari 6,0 $\mathrm{mg} / \mathrm{L}$ dapat meningkatkan produksi rumput laut secara signifikan. Produksi rumput laut tertinggi didapatkan pada salinitas air 25,6 ppt dan rumput laut tumbuh baik pada kisaran pH antara 6,00 dan 9,32; fosfat lebih besar $0,1000 \mathrm{mg} / \mathrm{L}$; dan besi kurang dari $0,1000 \mathrm{mg} / \mathrm{L}$.

KATA KUNCI : optimalisasi, lahan, tambak, Luwu Utara

\section{PENDAHULUAN}

Sampai tahun 2005, luas tambak di pantai Timur Provinsi Sulawesi Selatan mencapai 42.839 ha (Anonim, 2005). Tambak tersebut tersebar di Kabupaten Luwu Timur (Lutim), Luwu Utara (Lutra), Luwu, Wajo, Bone, dan Sinjai, serta Kota Palopo dengan luas masing-masing berturutturut 5.441, 7.628, 4.408, 12.988, 10.810, 678, dan 916 ha. Produktivitas tambak di pantai Timur Provinsi Sulawesi Selatan masih tergolong rendah, terutama untuk udang dan bandeng. Pantai Timur Sulawesi Selatan juga masih memiliki potensi lahan seluas 15.000 ha untuk budidaya tambak (DKP, 2005). Dengan demikian, masih ada peluang peningkatan produksi budidaya tambak di pantai Timur Sulawesi Selatan, baik melalui intensifikasi, ekstensifikasi, maupun diversifikasi.

Dalam kaitannya dengan sumberdaya alam, dikenal istilah lahan dan tanah yang pengertiannya seringkali rancu. Sesungguhnya pengertian lahan lebih luas daripada tanah sebagaimana dalam pengertian berikut ini. Sumberdaya lahan merupakan suatu lingkungan fisik yang terdiri atas tanah, air, iklim, topografi, dan vegetasi di mana pada batasbatas tertentu memengaruhi kemampuan penggunaan lahan. Dengan demikian dalam pengertian lahan, tanah termasuk di dalamnya.

Salah satu jenis tanah yang umum dijumpai di pantai Timur Provinsi Sulawesi Selatan termasuk Kabupaten Lutra adalah tanah sulfat masam. Tanah sulfat masam adalah tanah yang mengandung besi sulfida atau pirit yang dicirikan dengan $\mathrm{pH}$ yang rendah dan ketersediaan unsurunsur beracun yang tinggi, sehingga produktivitasnya relatif rendah. Alternatif pengelolaan untuk tanah sulfat masam meliputi: pelarangan penggunaan; pencegahan terjadinya oksidasi; pemindahan material pirit; netralisasi dengan 
PETA SEBARAN TAMBAK DI KABUPATEN LUWU UTARA SULAWESI SELATAN TAHUN 2002
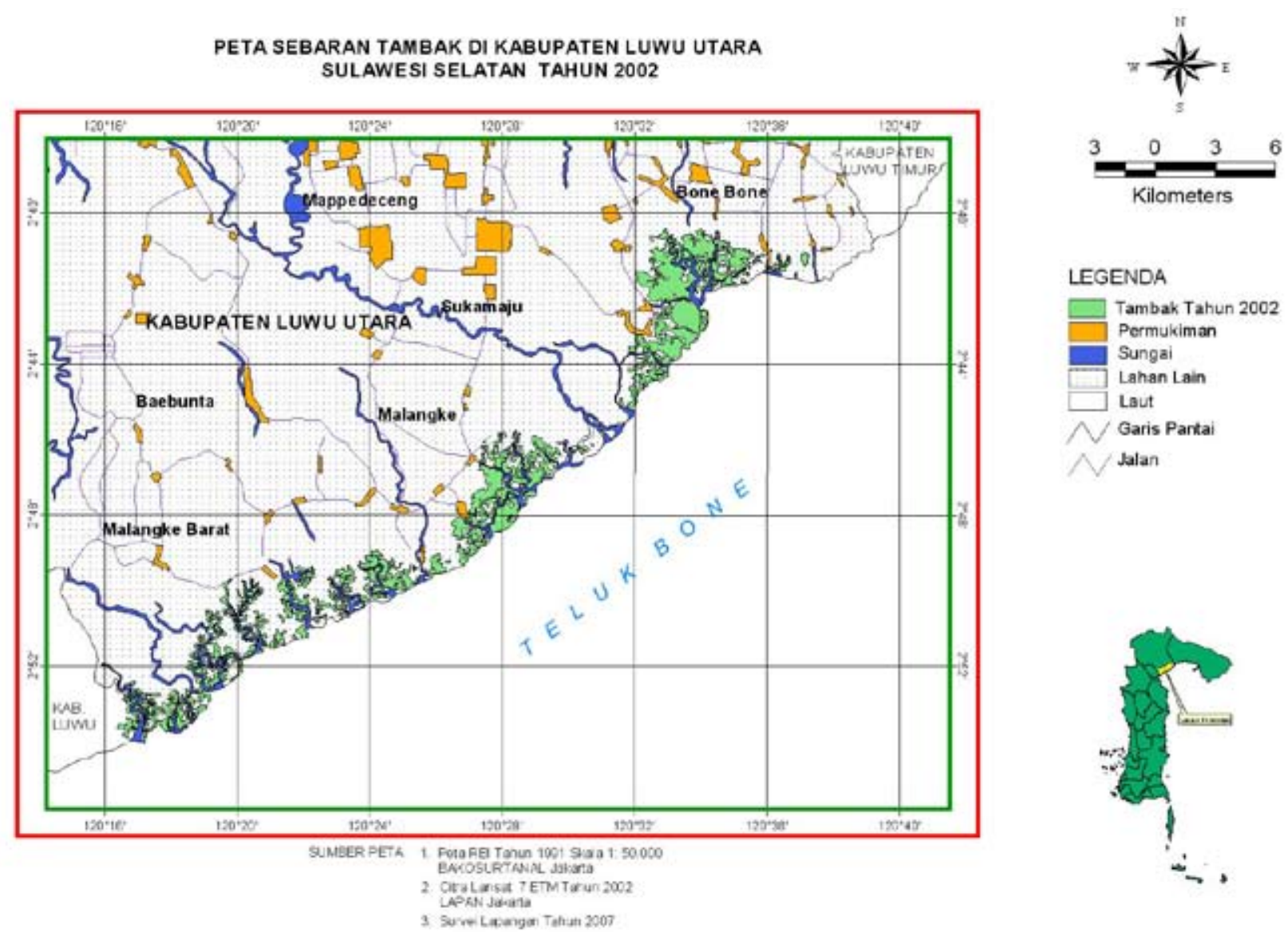

Sumber: $\quad$ Paena et al. (2008)

Gambar 1. Luas tambak di Kabupaten Luwu Utara Provinsi Sulawesi Selatan tahun 2002

bahan kimia; pemilihan lokasi; pemilihan komoditas; remediasi melalui oksidasi dan pembilasan serta penutupan dan pemadatan.

Budidaya rumput laut adalah kegiatan yang berwawasan lingkungan dan produktif bagi penduduk di kawasan pesisir (Sukadi, 2006). Rumput laut (Gracilaria verrucosa) adalah salah satu komoditas perikanan yang telah dibudidayakan di tambak termasuk tambak tanah sulfat masam di bagian Utara pantai Timur Provinsi Sulawesi Selatan seperti Kabupaten Lutra. Tambak yang tidak lagi produktif untuk udang dan ikan dapat digunakan bagi usaha budidaya rumput laut, akan tetapi harus memenuhi persyaratan teknis dan biologis (Mubarak et al., 1990). Telah dilaporkan bahwa kualitas rumput laut dari bagian Utara pantai Timur Provinsi Sulawesi Selatan merupakan salah satu yang terbaik di Indonesia (Anonim, 2003). Selain memiliki daya saing yang bagus karena didukung oleh kondisi bibit rumput laut yang berkualitas budidaya juga dapat dilakukan sepanjang tahun (Mira \& Reswati, 2006).
Oleh karena itu, optimalisasi sumberdaya lahan terutama tanah sulfat masam perlu dipertimbangkan dapat berdaya guna dan berhasil guna. Dalam makalah ini akan dibahas mengenai potensi lahan, kesesuaian lahan, kondisi lingkungan, dan pengelolaan tambak untuk budidaya rumput laut agar sumberdaya lahan tambak di Kabupaten Lutra dapat terpenuhi secara optimal.

\section{Potensi Lahan}

Dengan teknologi Inderaja (penginderaan jauh) dan sistem informasi geografis (SIG) didapatkan peningkatan luas tambak di Kabupaten Lutra dari tahun 2002 sampai 2005 sebesar 2.900,10 ha yaitu dari 4.938,84 (Gambar 1) menjadi 7.838,94 ha (Gambar 2) atau terjadi penambahan luas tambak sebesar 966,70 ha/tahun (19,57\%). Telah dilaporkan bahwa luas tambak di Kabupaten Lutra pada tahun 2005 adalah 7.628 ha (Anonim, 2005); sedikit lebih rendah dibandingkan dengan hasil yang diperoleh dengan teknologi Inderaja dan SIG yang diduga sebagai 
PETA SEBARAN TAMBAK DI KABUPATEN LUWU UTARA SULAWESI SELATAN TAHUN 2005
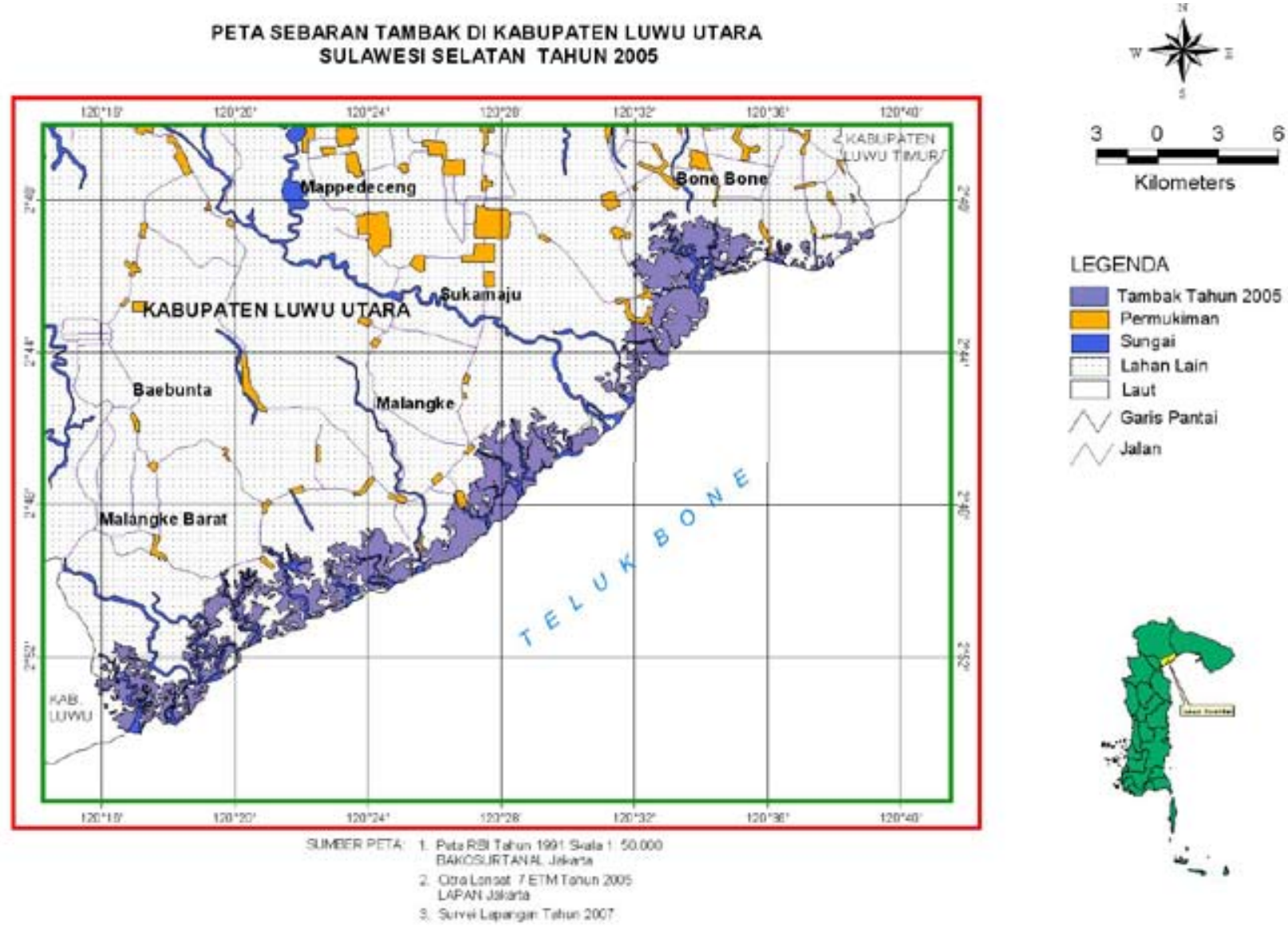

Sumber:

Paena et al. (2008)

Gambar 2. Luas tambak di Kabupaten Luwu Utara Provinsi Sulawesi Selatan tahun 2005

akibat adanya perbedaan metode dalam penentuan luas tambak. Ada tiga faktor yang mendorong pembukaan lahan tambak di Kabupaten Lutra yaitu penggunaan lahan untuk permukiman di wilayah pesisir sangat kecil (pusat permukiman lebih ke arah darat), karakteristik lahan yang cocok mendukung untuk membuka lahan tambak yang baru; dan harga komoditas rumput laut yang dianggap mampu mengangkat kesejahteraan pembudidaya tambak. Penyebab lain yang mendorong pembukaan tambak di Kabupaten Lutra adalah ketersediaan sumberdaya air yang cukup memadai baik secara kualitas maupun kuantitas.

\section{Kesesuaian Lahan}

Dari luas potensi lahan tambak di Kabupaten Lutra, ternyata $3.527,3$ ha tergolong sangat sesuai (kelas S1); 490,9 ha tergolong cukup sesuai (kelas S2); dan 7.280,8 ha tergolong kurang sesuai (kelas S3) (Gambar 3). Sebagai faktor pembatas utama kesesuaian lahan tambak di Kabupaten Lutra adalah potensi kemasaman tanah yang tinggi terutama di Kecamatan Malangke. Bahan organik tanah yang tinggi juga dapat menjadi faktor pembatas dalam kesesuaian lahan tambak di Kecamatan Malangke Timur, demikian juga tekstur tanah yang tergolong kasar, terutama untuk penerapan teknologi tradisional, sebab klekap sebagai makanan alami di tambak akan sangat sulit untuk tumbuh. Pada musim hujan, salinitas air sangat rendah, sekitar 8 ppt dapat juga menjadi faktor pembatas.

\section{Kebutuhan Faktor Lingkungan untuk Budidaya Rumput Laut}

Dua faktor lingkungan yang sangat besar pengaruhnya terhadap produktivitas tambak termasuk rumput laut (Gracilaria verrucosa) adalah kualitas air dan kualitas tanah. Rumput laut tidak memiliki bagian khusus yang dapat menyerap unsur hara, seperti akar pada tanaman secara umum, tetapi seluruh bagian tubuh rumput laut dapat menyerap unsur hara dari air. Sementara kualitas air dapat dipengaruhi oleh kualitas tanah dasar dan pematang tambak. 


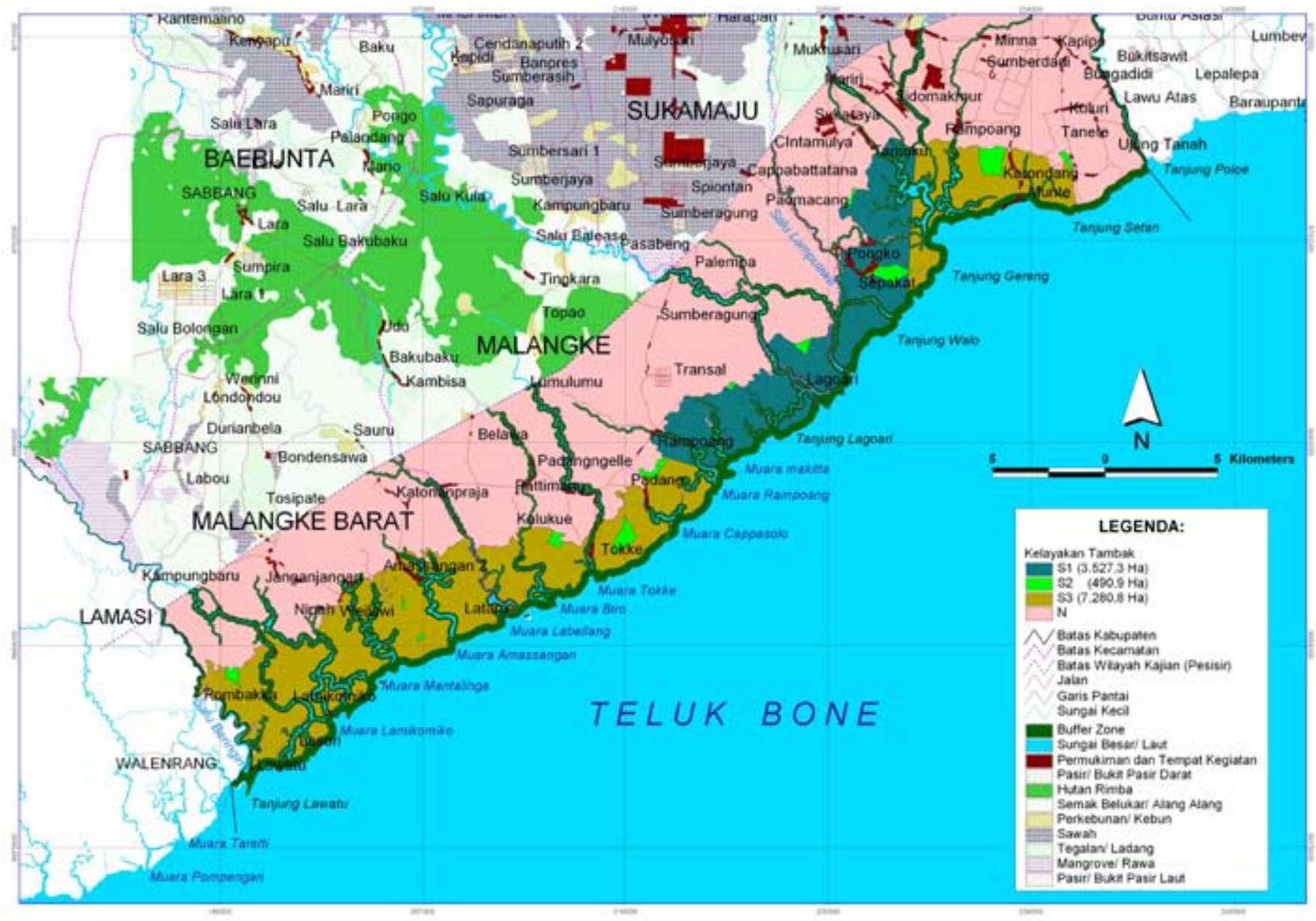

Sumber: $\quad$ Hasnawi \& Mustafa (2010)

Gambar 3. Kesesuaian lahan tambak di Kabupaten Luwu Utara Provinsi Sulawesi Selatan

\section{Kualitas Tanah}

Derajat kemasaman atau pH tanah merupakan penciri utama tanah sulfat masam dan menggambarkan kondisi kemasaman, proses kimia yang mungkin terjadi, serta akibatnya terhadap kualitas tanah. Baik $\mathrm{pH}_{\mathrm{F}}$ maupun $\mathrm{pH}_{\mathrm{Fox}}$ tanah memiliki hubungan yang sangat nyata terhadap produksi rumput laut di tambak, di mana terlihat bahwa makin tinggi $\mathrm{pH}$ maka makin tinggi pula produksi rumput laut. Pengaruh keduanya terhadap produksi rumput laut juga relatif sama besarnya yaitu $\mathrm{pH}_{\mathrm{F}}$ berkontribusi sebesar 45,8\%; sedangkan $\mathrm{pH}_{\text {Fox }}$ berkontribusi sebesar 46,0\% terhadap produksi rumput laut. Telah dilaporkan oleh Mustafa \& Sammut (2010) bahwa peningkatan 1 unit $\mathrm{pH}_{\text {Fox }}$ sampai kondisi netral dapat meningkatkan produksi rumput laut 204 kg kering/ha/tahun di Kabupaten Luwu.

Selisih antara $\mathrm{pH}_{\mathrm{F}}$ dan $\mathrm{pH}_{\mathrm{FOX}}\left(\mathrm{pH}_{\mathrm{F}}-\mathrm{pH}_{\mathrm{FOX}}\right)$ dapat menggambarkan potensi kemasaman dari tanah sulfat masam. $\mathrm{pH}_{\mathrm{F}}-\mathrm{pH}_{\mathrm{FOx}}$ juga berhubungan secara sangat nyata di mana penurunan nilai $\mathrm{pH}_{\mathrm{F}}-\mathrm{pH}_{\mathrm{Fox}}$ diikuti dengan peningkatan produksi rumput laut. Dari hasil analisis peubah-peubah kualitas tanah yang menggambarkan kemasaman tanah menunjukkan bahwa rumput laut dapat tumbuh dengan baik pada $\mathrm{pH}$ tanah yang lebar dan diperlihatkan oleh model regresi yang umumnya bersifat linier positif (Gambar 4). Dalam kondisi seperti ini, pH optimum belum dapat ditentukan. Namun demikian, produksi rumput laut yang lebih tinggi didapatkan pada tanah dengan $\mathrm{pH}_{\mathrm{F}}$ lebih besar 6,5; $\mathrm{pH}_{\mathrm{Fox}}$ lebih besar 4,0; dan $\mathrm{pH}_{\mathrm{F}}-\mathrm{pH}_{\mathrm{FOX}}$ kurang dari 2,5.

Kandungan $\mathrm{PO}_{4}$ tanah sangat nyata pengaruhnya terhadap produksi rumput laut di tambak, di mana makin tinggi kandungan $\mathrm{PO}_{4}$ tanah maka semakin tinggi pula produksi rumput laut. Telah diketahui bahwa kandungan $\mathrm{PO}_{4}$ pada tanah sulfat masam umumnya sangat rendah 
a

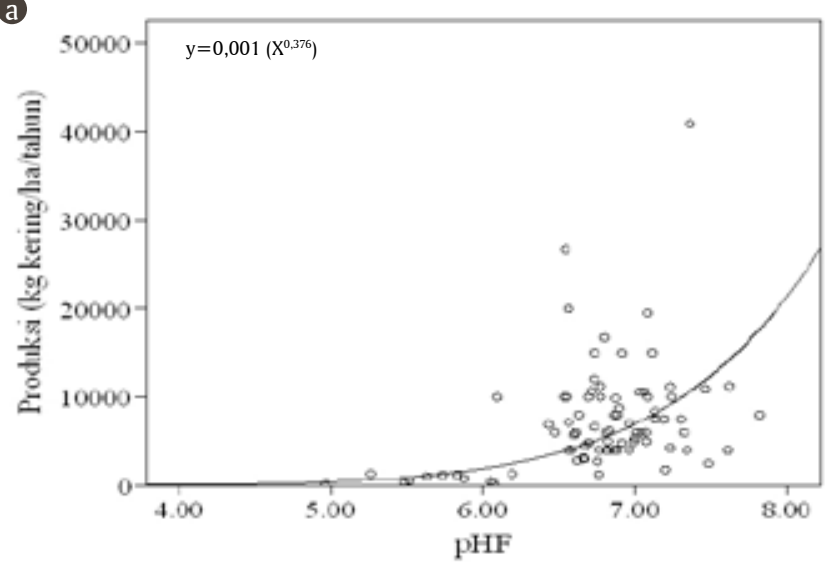

C

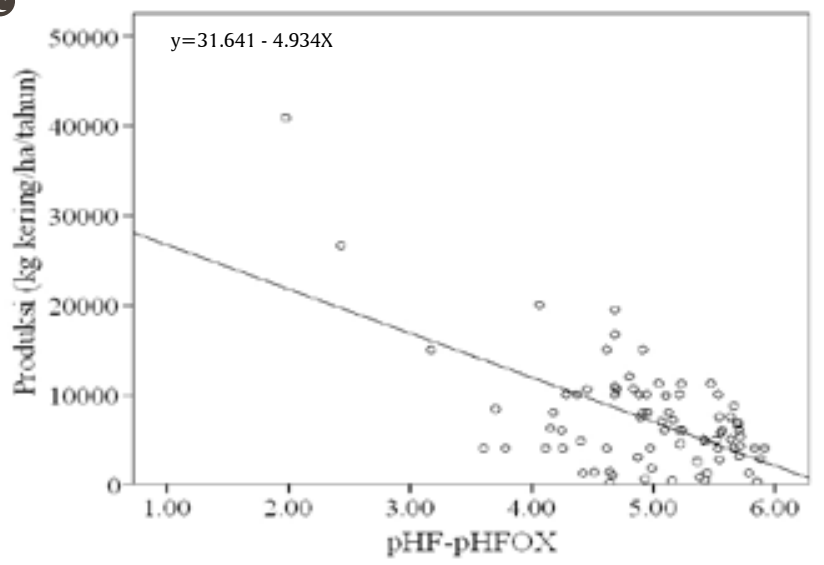

e

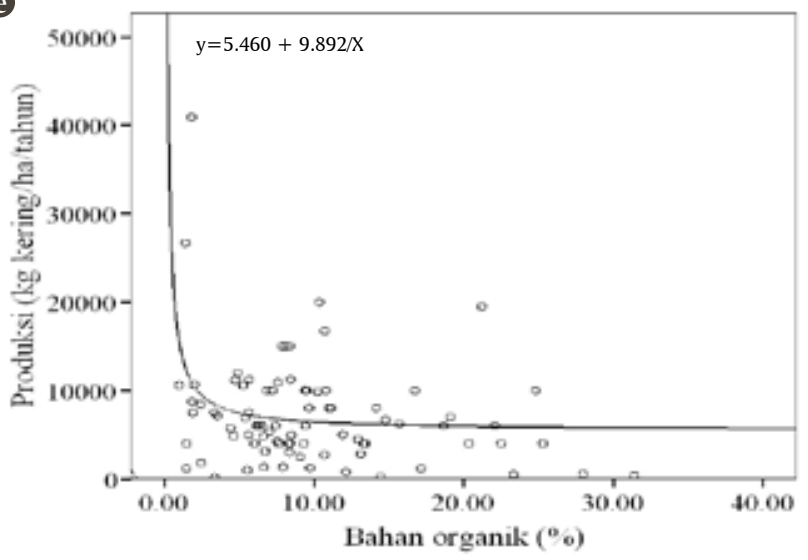

(b)

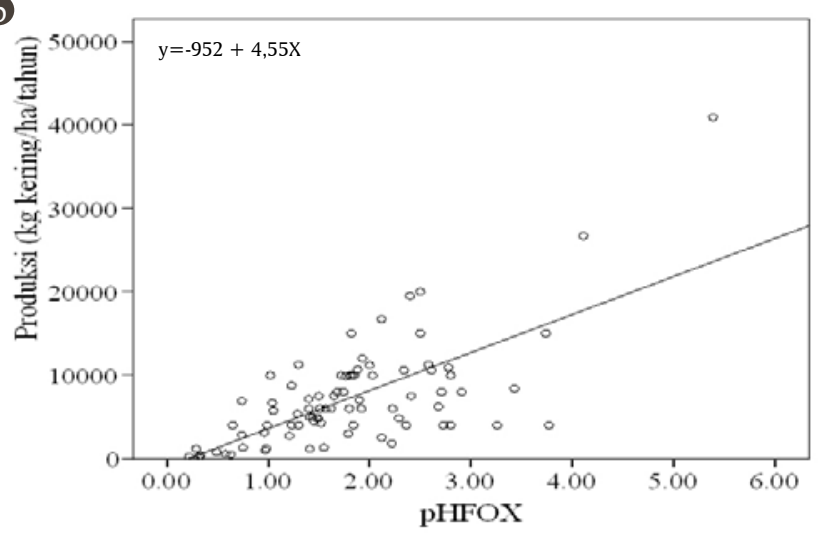

(d)

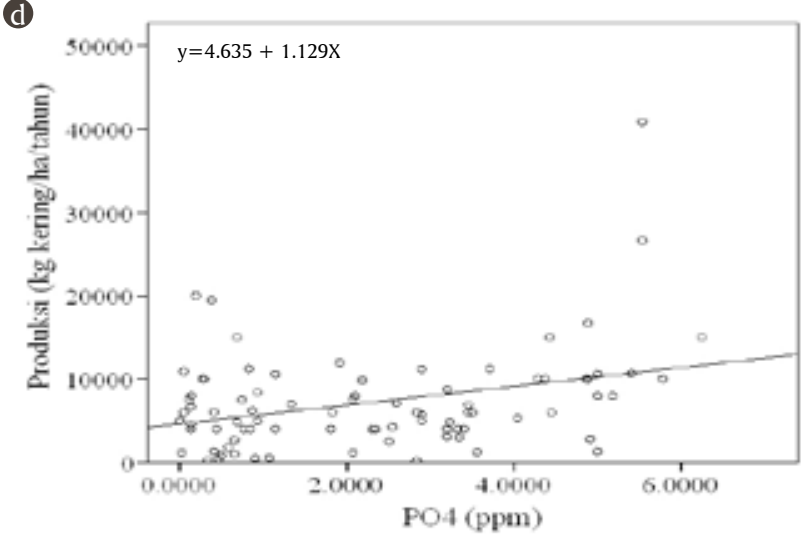

f

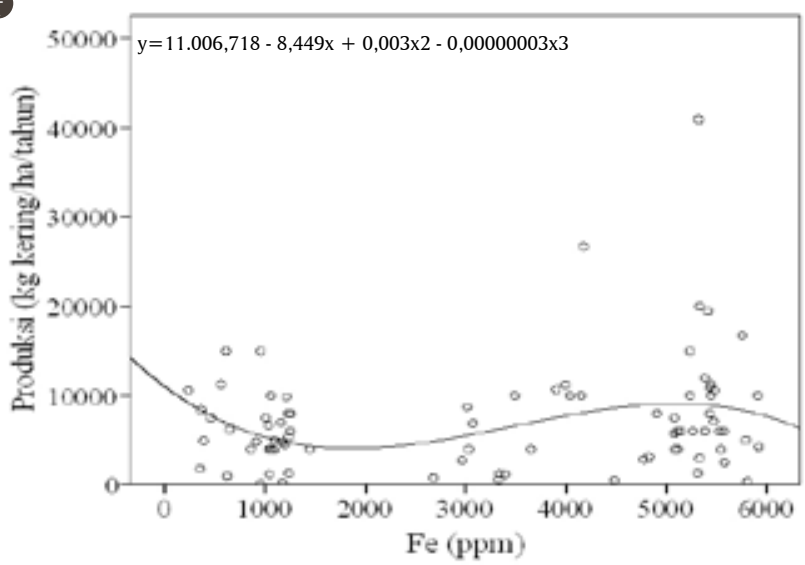

Sumber: $\quad$ Mustafa et al. (2008)

Gambar 4. Hubungan antara produksi rumput laut (Gracilaria verrucosa) dan $\mathrm{pH}_{\mathrm{F}}, \mathrm{pH}_{\mathrm{FOX}}, \mathrm{pH}_{\mathrm{F}}-\mathrm{pH}_{\mathrm{FOX}}, \mathrm{PO}_{4}$, bahan organik, dan Fe tanah tambak di pantai Timur Provinsi Sulawesi Selatan 
sebab terikat oleh Fe dan $\mathrm{Al}$, sehingga menjadi kurang ketersediaannya bagi organisme akuatik termasuk rumput laut. Selain itu, pembudidaya rumput laut seperti di Kabupaten Lutra dan Luwu hanya memberikan pupuk yang mengandung fosfat dalam dosis yang kecil, padahal $\mathrm{P}$ merupakan unsur penting bagi semua aspek kehidupan terutama dalam transformasi energi metabolik.

Telah disebutkan sebelumnya bahwa tambak yang digunakan untuk budidaya rumput laut di pantai Timur Provinsi Sulawesi Selatan umumnya didominasi oleh tanah sulfat masam. Tanah sulfat masam ini biasanya berasosiasi dengan tanah gambut sehingga kandungan bahan organik tanah dapat mencapai 31,4\% dengan rata-rata 9,8\%. Bahan organik yang telah terdekomposisi dapat menjadi sumber hara bagi rumput laut, namun demikian jika kandungannya terlalu tinggi dapat menghambat pertumbuhan rumput laut. Dekomposisi bahan organik juga dapat menghasilkan $\mathrm{CO}_{2}$ (karbon dioksida), $\mathrm{H}_{2} \mathrm{~S}$ (hidrogen sulfida), dan $\mathrm{CH}_{4}$ (metan) yang tinggi dan dapat menghambat pertumbuhan organisme akuatik.

Fe dan Al adalah logam yang melimpah di tanah sulfat masam. Kandungan Fe tanah berkorelasi secara nyata dan pada kandungan lebih besar dari $5.000 \mathrm{mg} / \mathrm{L}$ berdampak pada penurunan produksi rumput laut. Besi dibutuhkan oleh tanaman termasuk rumput laut sebagai penyusun sitokrom dan klorofil, serta berperan dalam sistem enzim dan transfer elektron pada proses fotosintesis (Effendi, 2003). Besi adalah logam yang dibutuhkan oleh alga paling besar dibandingkan dengan logam lainnya (Malea \& Haritinodis, 1999; Caliceti et al., 2002). Namun demikian, kelebihan Fe tanah berdampak pada pengikatan unsur hara tertentu seperti fosfat menjadi tidak tersedia bagi rumput laut. Mustafa \& Sammut (2007) telah melaporkan adanya korelasi yang sangat nyata antara kandungan $\mathrm{Fe}$ dan P-tersedia di mana makin tinggi kandungan Fe maka kandungan P-tersedia makin kecil. Selain itu, kelebihan Fe dapat menyebabkan keracunan pada tanaman sebagai contoh pada tanaman padi (Oriza sativa), yang sebagian mengalami keracunan pada kandungan $\mathrm{Fe} 500 \mathrm{mg} / \mathrm{L}$ (Ponnamperuma, 1976).

Kandungan $\mathrm{Al}$ berhubungan tidak nyata dengan produksi rumput laut di tambak. Dalam hal ini, pada kandungan Al tanah antara 96 mg/L dan 1.195 mg/L belum memberikan pengaruh terhadap produksi rumput laut. Namun demikian, ada kecenderungan penurunan produksi rumput laut pada tanah dengan kandungan Al melebihi 490 $\mathrm{mg} / \mathrm{L}$ (Gambar 5). Kelarutan Al yang tinggi menyebabkan pembelahan dan perkembangan sel terhambat akibat enzim yang melakukan sintesis bahan dari dinding sel terganggu (Rorison, 1973).

Pada tanah sulfat masam maupun yang berasosiasi dengan tanah gambut menunjukkan kandungan liat yang sangat rendah bahkan beberapa contoh tanah tidak terdeteksi kandungan liatnya. Kandungan pasir sangat nyata pengaruhnya terhadap produksi rumput laut di mana makin rendah kandungan pasir makin tinggi produksi rumput laut. Hal ini sangat terkait dengan sifat fisik dan kimia dari fraksi pasir. Tambak dengan kandungan pasir yang tinggi berdampak pada tingginya porositas pematang yang menyebabkan tinggi air tambak tidak bisa bertahan. Dikatakan oleh Mubarak et al. (1990), bahwa lahan untuk budidaya rumput laut di tambak sebaiknya mempunyai dasar tambak yang bertekstur lempung berpasir, apabila dasar tambaknya memiliki porositas tinggi maka sangat sulit mempertahankan kedalaman air. Ada kemungkinan rendahnya tinggi air pada tambak yang didominasi fraksi pasir berdampak pada rendahnya produksi rumput laut.

Dalam hubungannya dengan sifat kimia dari fraksi pasir, adalah kekurangmampuan pasir untuk menyerap air, ion-ion anorganik, bahan organik, dan gas-gas pada permukaannya, sebagai akibatnya, tanah yang didominasi fraksi pasir cenderung kandungan haranya lebih rendah. Tanah dengan kandungan fraksi pasir juga memiliki daya sangga yang rendah sehingga fluktuasi pH dapat lebih besar yang dapat pula mengganggu pertumbuhan rumput laut.

Kebalikan dari pengaruh fraksi pasir adalah adanya kandungan debu yang menyebabkan peningkatan produksi rumput laut. Secara fisik, tingginya kandungan fraksi liat dan debu berdampak pada lebih kompaknya dasar tambak maupun pematang sehingga kedalaman air dapat dipertahankan. Secara kimia, dengan kandungan fraksi liat dan debu sampai nilai tertentu menunjukkan kondisi tanah yang lebih baik. Menurut Schaetzl \& Anderson (2005), debu memiliki kemampuan menyimpan unsur hara yang tergolong rendah dan liat tergolong sedang sampai tinggi, sedangkan pasir tergolong sangat rendah. Tanah bertekstur 

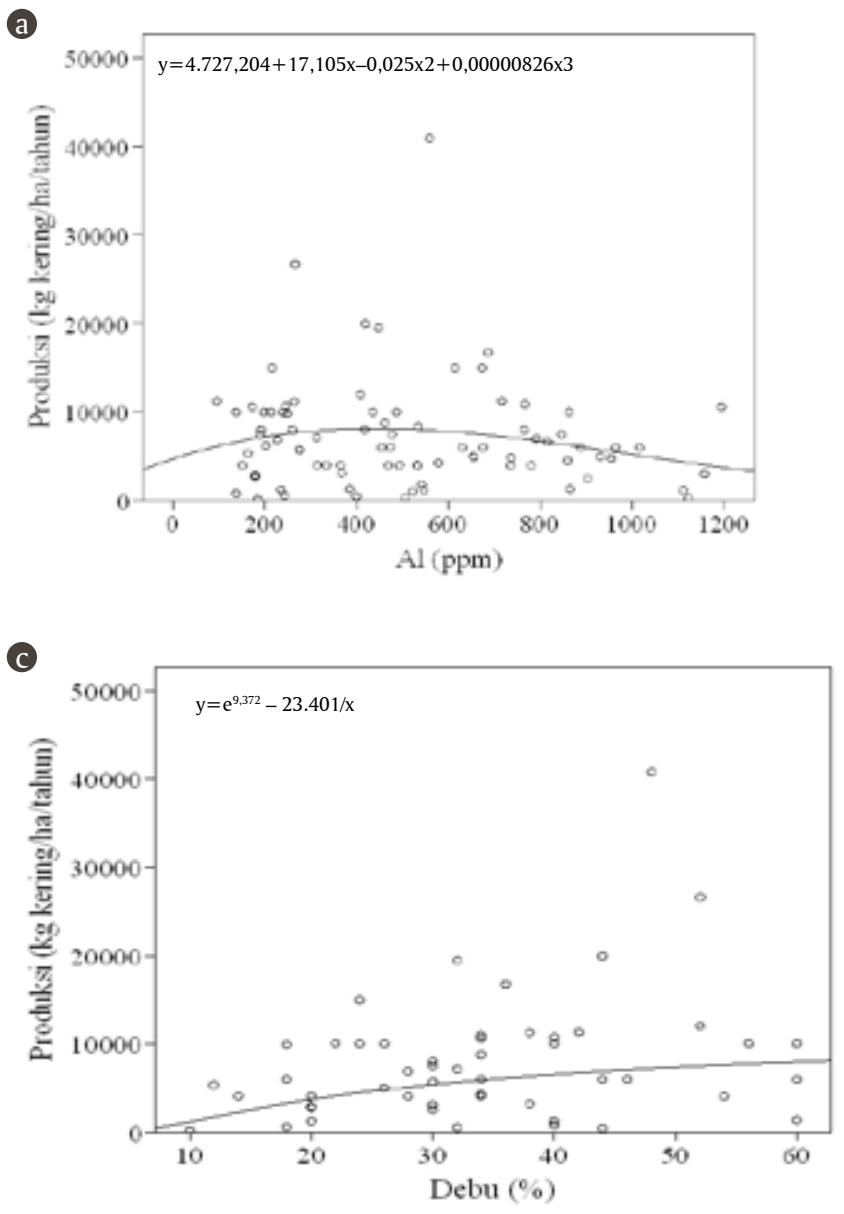

liat atau debu, karena lebih halus maka setiap satuan berat mempunyai luas permukaan yang lebih besar sehingga kemampuan menahan air dan menyimpan unsur hara lebih tinggi. Dengan demikian ketersediaan unsur hara lebih terjamin dibandingkan dengan tanah dengan fraksi pasir.

\section{Kualitas Air}

Hubungan antara produksi rumput laut dengan berbagai peubah kualitas air di tambak di pantai Timur Provinsi Sulawesi Selatan termasuk Kabupaten Lutra terlihat pada Gambar 6. Produksi rumput laut tertinggi didapatkan pada salinitas 25,6 ppt. Seperti dilaporkan oleh Tseng \& Borowitzka (2003) sebelumnya bahwa rumput laut tumbuh paling cepat pada salinitas 25 ppt dan Mubarak et al. (1990) menyatakan bahwa rumput laut tumbuh baik pada salinitas antara 18 dan 30 ppt. Tseng \& Borowitzka (2003) menyatakan bahwa rumput laut mulai mati pada salinitas lebih dari 35 ppt. Oleh karena itu, sumber air tawar dan air laut di tambak menjadi penting agar salinitas optimum dapat dipenuhi.

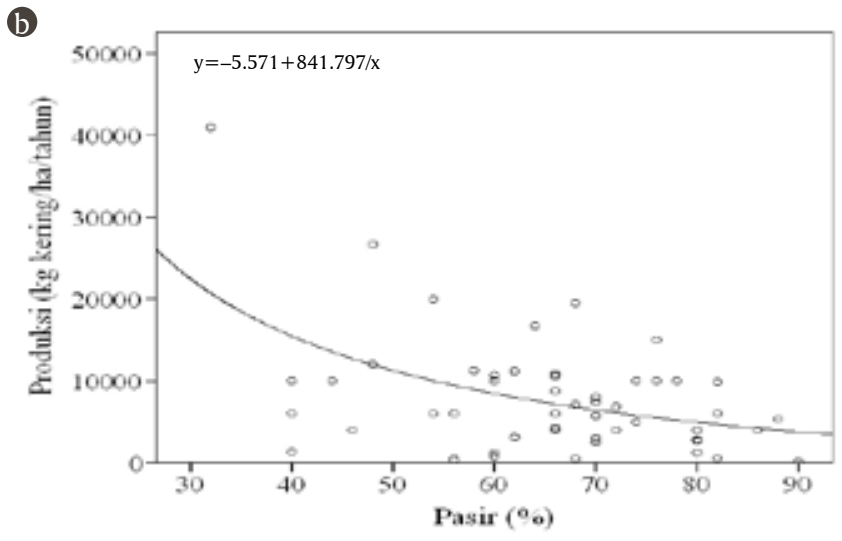

$\begin{array}{ll}\text { Sumber: } & \text { Mustafa et al. (2008) } \\ \text { Gambar 5. } & \text { Hubungan antara produksi rumput laut } \\ & \text { (Gracilaria verrucosa) dan Al, pasir, dan debu dari } \\ & \text { tanah tambak di pantai Timur Provinsi Sulawesi } \\ & \text { Selatan }\end{array}$

Suhu air tambak yang digunakan untuk budidaya rumput laut di pantai Timur Provinsi Sulawesi Selatan berkisar $26,0^{\circ} \mathrm{C}$ dan $37,9^{\circ} \mathrm{C}$ dengan rata-rata $31,7^{\circ} \mathrm{C}$. Diduga kisaran suhu air tambak tersebut belum signifikan memengaruhi produksi rumput laut. Suhu air $25^{\circ} \mathrm{C}-30^{\circ} \mathrm{C}$ adalah suhu yang baik untuk budidaya rumput laut (Hurtado-Ponce \& Umezaki, 1987). Suhu air untuk budidaya rumput laut sebaiknya antara $20^{\circ} \mathrm{C}$ dan $28^{\circ} \mathrm{C}$ dengan fluktuasi harian maksimal $4^{\circ} \mathrm{C}$ (Mubarak et al., 1990).

Potensi kemasaman tanah yang cukup bervariasi besarnya berdampak pula pada $\mathrm{pH}$ air tambak yang cukup bervariasi. Rumput laut dapat tumbuh baik pada kisaran $\mathrm{pH}$ air yang lebar dari 6,0-9,3. Pada pH kurang dari 4,0 sebagian tumbuhan air akan mati karena tidak dapat bertoleransi terhadap pH rendah (Effendi, 2003).

Pasokan unsur hara merupakan salah satu faktor yang memengaruhi pertumbuhan rumput laut. Unsur hara seperti nitrogen dapat diserap oleh rumput laut dalam bentuk $\mathrm{NH}_{4}$ (amonium) dan $\mathrm{NO}_{3}$, di mana $\mathrm{NH}_{4}$ lebih disukai daripada $\mathrm{NO}_{3}$ (Yang et al., 2006). Terdapat hubungan sangat 
a

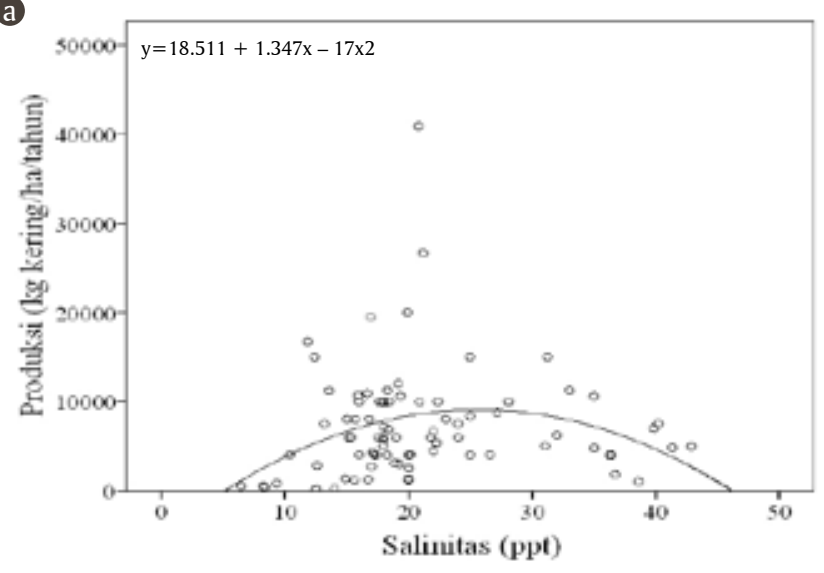

c

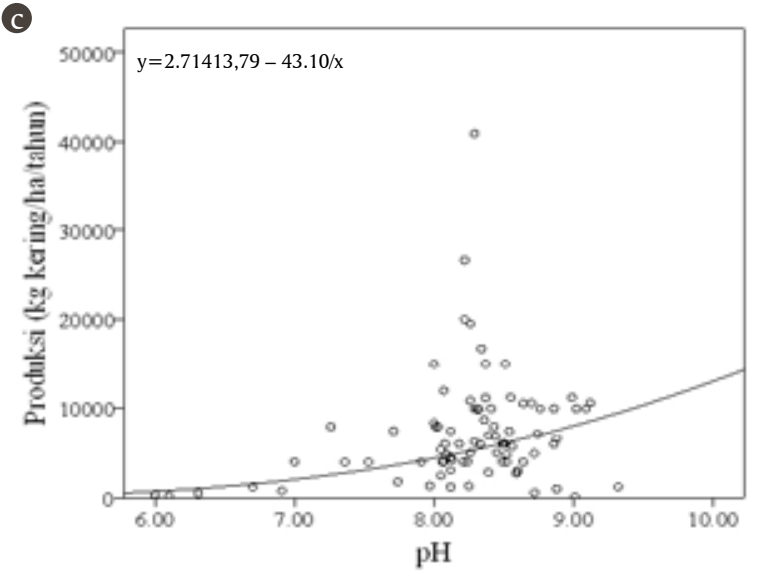

e

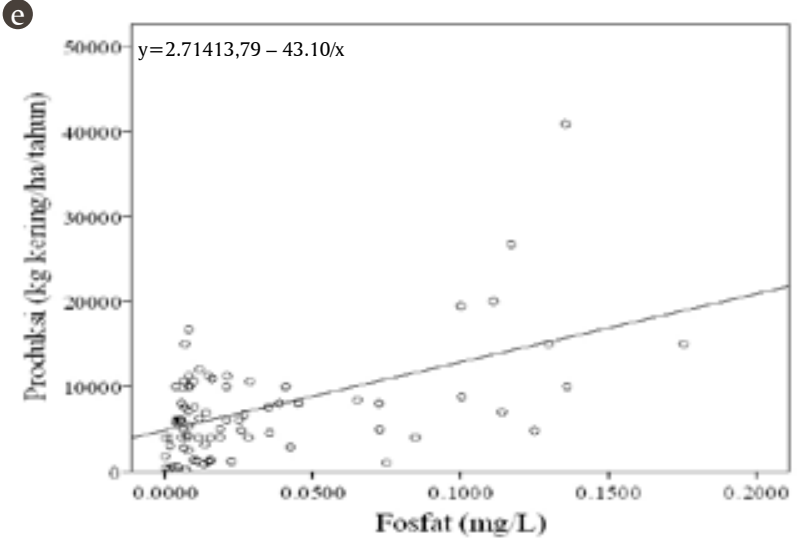

b

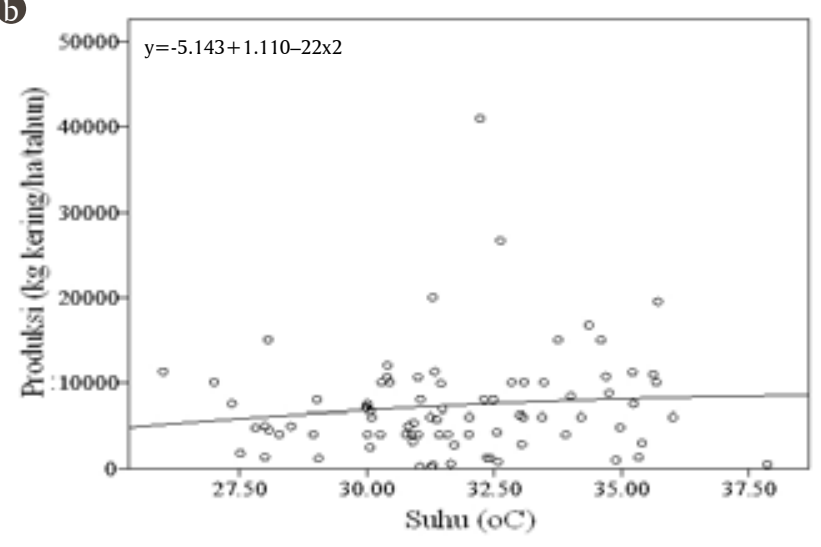

d

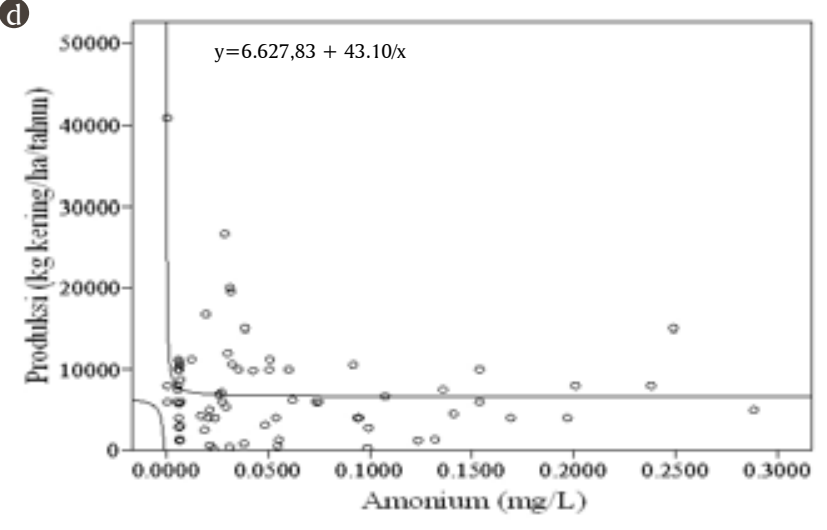

d

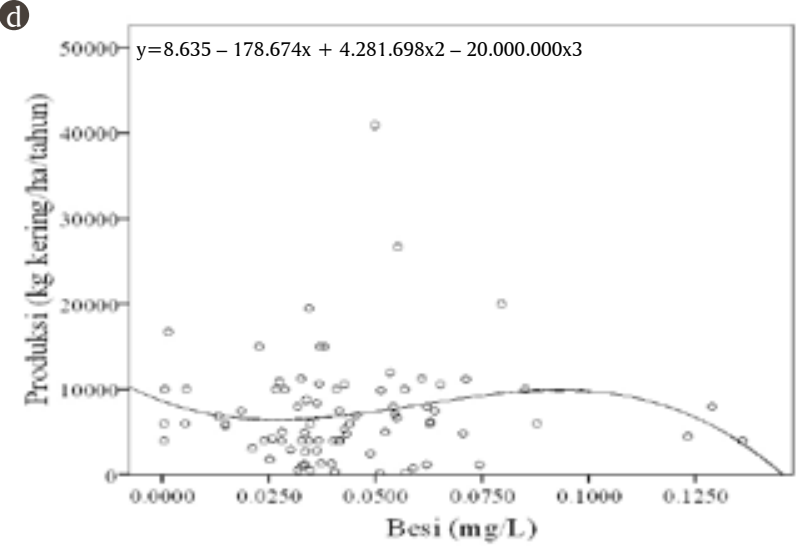

Sumber: $\quad$ Mustafa et al. (2007)

Gambar 6. Hubungan antara produksi rumput laut (Gracilaria verrucosa) dan salinitas, suhu, pH, amonium, fosfat, dan besi air tambak di pantai Timur Provinsi Sulawesi Selatan 
Gambar 7. Curah hujan bulanan di kawasan pesisir Kabupaten Luwu Utara Provinsi Sulawesi Selatan

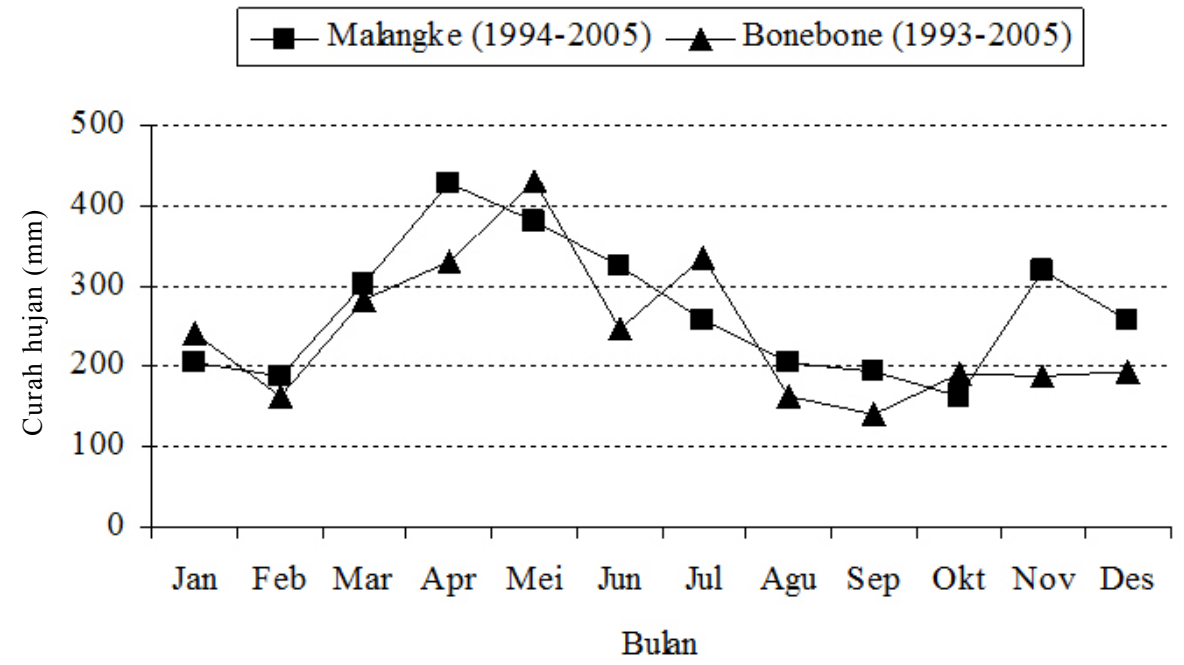

nyata antara kandungan $\mathrm{NH}_{4}$ dan produksi rumput laut yang menunjukkan makin rendah kandungan $\mathrm{NH}_{4}$ dalam air maka produksi rumput laut lebih tinggi. Telah dilaporkan oleh Mustafa \& Ratnawati (2005) serta Mustafa \& Sammut (2010) bahwa penambahan dosis pupuk yang mengandung nitrogen di Kabupaten Luwu Provinsi Sulawesi Selatan dapat menurunkan produksi rumput laut.

Fosfor (P) merupakan unsur yang esensial bagi tumbuhan tingkat tinggi dan alga akuatik, sehingga unsur ini menjadi faktor pembatas bagi tumbuhan dan alga akuatik, serta sangat memengaruhi tingkat produktivitas perairan. Kandungan $\mathrm{PO}_{4}$ air tambak pada budidaya rumput laut rata-rata $0,0303 \mathrm{mg} / \mathrm{L}$ dan tergolong perairan dengan tingkat kesuburan sedang (Liaw, 1969). Dengan demikian, peningkatan kandungan $\mathrm{PO}_{4}$ dapat meningkatkan produksi rumput laut. Selain itu, dikenal pula istilah "konsumsi lebih" pada alga akuatik yaitu pada saat perairan cukup mengandung P, alga akuatik mengakumulasi P di dalam sel melebihi kebutuhannya (Boney, 1989). Kelebihan P yang diserap akan dimanfaatkan pada saat perairan kekurangan $P$, sehingga rumput laut masih dapat tumbuh selama beberapa waktu selama periode kekurangan pasokan P.

Besi (Fe) termasuk unsur yang esensial bagi makhluk hidup. Pada tumbuhan, termasuk rumput laut, Fe berperan sebagai penyusun sitokrom dan klorofil, serta berperan dalam sistem enzim dan transfer elektron pada proses fotosintesis. Kisaran kandungan Fe air tambak pada budidaya rumput laut dari 0,0004-0,1359 mg/L dengan rata-rata $0,0433 \mathrm{mg} / \mathrm{L}$; masih dalam kisaran yang bisa ditolerir oleh organisme akuatik sehingga tidak memberikan pengaruh yang nyata terhadap produksi rumput laut. Kandungan Fe pada perairan alami berkisar antara 0,05-0,20 mg/L (Boyd, 1990). Kandungan Fe air yang lebih tinggi dari 1,0 mg/L dianggap membahayakan kehidupan organisme akuatik (Moore, 1991). Selain itu, tanaman air dan alga mempunyai kemampuan untuk menyerap logam seperti Fe dan Al. Lebih lanjut Gosavi et al. (2004) menyatakan bahwa alga dapat menyerap Fe dan Al tiga kali lipat dibandingkan dengan logam lainnya. Tanaman air dan alga memiliki toleransi yang tinggi dibandingkan dengan ikan dan udang terhadap logam (Effendi, 2003).

\section{Remediasi Tambak untuk Budidaya Rumput Laut}

Perbaikan tanah sulfat masam berupa peningkatan $\mathrm{pH}$ tanah dan penurunan kandungan unsur toksik dapat dilakukan melalui remediasi. Remediasi adalah suatu aktivitas atau proses yang dilakukan untuk mengurangi unsur-unsur beracun dalam tanah (Mustafa \& Sammut, 2007). Remediasi yang dapat dilakukan berupa proses oksidasi dan pembilasan tanah, serta pemberian kapur.

Prinsip remediasi melalui oksidasi dan pembilasan tanah adalah pengeringan tanah untuk mengoksidasi pirit, perendaman untuk melarutkan dan menetralisir kemasaman atau menurunkan produksi kemasaman lanjut dan pembilasan untuk membuang hasil oksidasi dan meminimalkan cadangan unsur-unsur beracun dalam tanah. 


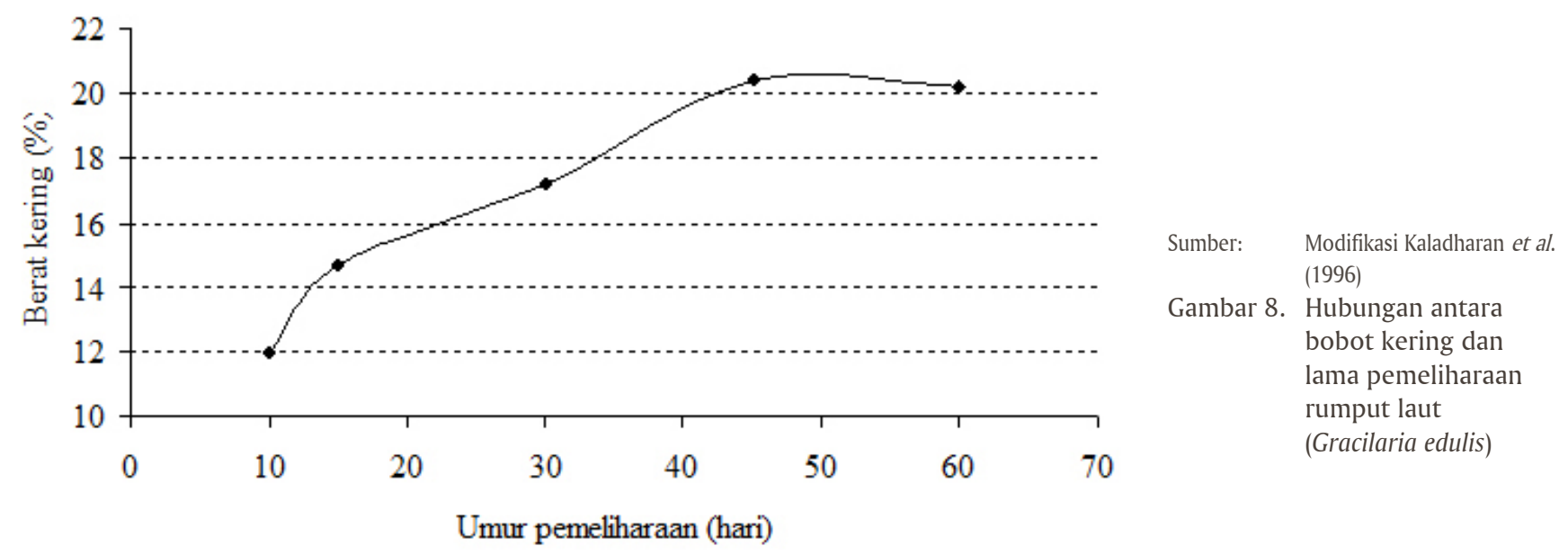

Sebelum tanah tambak diremediasi melalui proses oksidasi dan pembilasan, sebaiknya pematang dan pintu air tambak diperbaiki terutama jika ada kebocoran dan perembesan agar pengeringan tanah dapat lebih sempurna. Tanah dasar tambak sebaiknya dicangkul terlebih dahulu sedalam 20 $\mathrm{cm}$ agar permukaan tanah bertambah luas sehingga proses oksidasi dapat lebih baik. Pengeringan tanah dasar tambak dilakukan selama 2 minggu pada keadaan terik matahari atau tergantung pada keadaan cuaca selama pengeringan. Kemudian tambak direndam selama 1 minggu dan air rendaman dibuang. Proses tersebut diulang 2 atau 3 kali sampai didapatkan kondisi tanah yang lebih baik. Disarankan proses tersebut dilakukan pada musim kemarau di mana curah hujan relatif rendah yaitu pada bulan September dan Oktober di Kabupaten Lutra (Gambar 7) dan pada saat surut rendah agar pengeringan dapat lebih baik, salinitas air rendaman dapat lebih tinggi dan selanjutnya pembilasan air rendaman juga dapat lebih sempurna.

Bentuk lain remediasi berupa pengapuran dapat dilakukan untuk mengurangi unsur-unsur beracun yang masih tersisa dalam tanah. Bentuk kapur yang disarankan digunakan adalah kapur pertanian dan dolomit. Dolomit selain mengandung $\mathrm{Ca}$ juga mengandung $\mathrm{Mg}$ yang juga dibutuhkan oleh rumput laut. $\mathrm{Mg}$ sangat dibutuhkan oleh klorofil tanaman termasuk rumput laut. Dosis kapur yang diaplikasikan sangat tergantung pada $\mathrm{pH}$ tanah atau nilai $\mathrm{S}_{\mathrm{POS}}$, tekstur tanah dan berat jenis tanah yang akan dikapur dan nilai netralisir dan tingkat efisiensi kapur yang akan digunakan.

Telah disebutkan sebelumnya bahwa rumput laut memerlukan unsur hara makro untuk pertumbuhannya.
Unsur hara makro tersebut dapat dipasok melalui pemupukan seperti urea, SP-36, dan ZA. Pemberian pupuk dasar urea, TSP, dan ZA dapat meningkatkan produksi rumput laut di tambak Kabupaten Lutra (Ratnawati et al., 2008) dan Kabupaten Luwu (Mustafa \& Ratnawati, 2005; Mustafa \& Sammut, 2010). Khusus di tambak tanah sulfat masam, dosis aplikasi pupuk SP-36 dapat lebih tinggi dibandingkan dengan dosis pupuk lainnya, karena ketersediaan fosfat di tambak tanah sulfat masam relatif rendah.

Selanjutnya tambak diisi air, diusahakan air yang bersalinitas tinggi (lebih besar 15 ppt) dengan tinggi air 30-50 $\mathrm{cm}$. Kedalaman air tambak yang disarankan untuk budidaya rumput laut di tambak adalah antara 0,6-0,8 m. Kedalamam ini sudah dapat mendukung pertumbuhan rumput laut, sebaliknya menekan pertumbuhan klekap maupun lumut yang sering menjadi penghambat pertumbuhan rumput laut. Selain itu, sudah cukup mempertahankan suhu air yang diinginkan. Kondisi salinitas ini dapat dijumpai di Kabupaten Lutra pada musim kemarau.

Bibit rumput laut yang baik adalah talus yang muda, bercabang banyak, rimbun, sehat, tidak terdapat bercak, tidak ada luka ataupun terkelupas, dapat ditebar sebanyak $1.000-1.250 \mathrm{~kg}$ basah/ha. Penanaman rumput laut di tambak dilakukan dengan metode tebar yaitu dengan cara menebarkan rumpun bibit secara merata di dalam tambak. Bobot bibit rumput laut sebaiknya sekitar $100 \mathrm{~g}$ setiap rumpun. Sebaiknya rumput laut ditebar pada musim kemarau dengan harapan kualitas air relatif stabil. Dalam hal ini salinitas tidak terlalu rendah dan juga pencucian asam-asam dari pematang yang dapat menurunkan kualitas air terutama $\mathrm{pH}$ dan alkalinitas dapat dikurangi. Untuk 


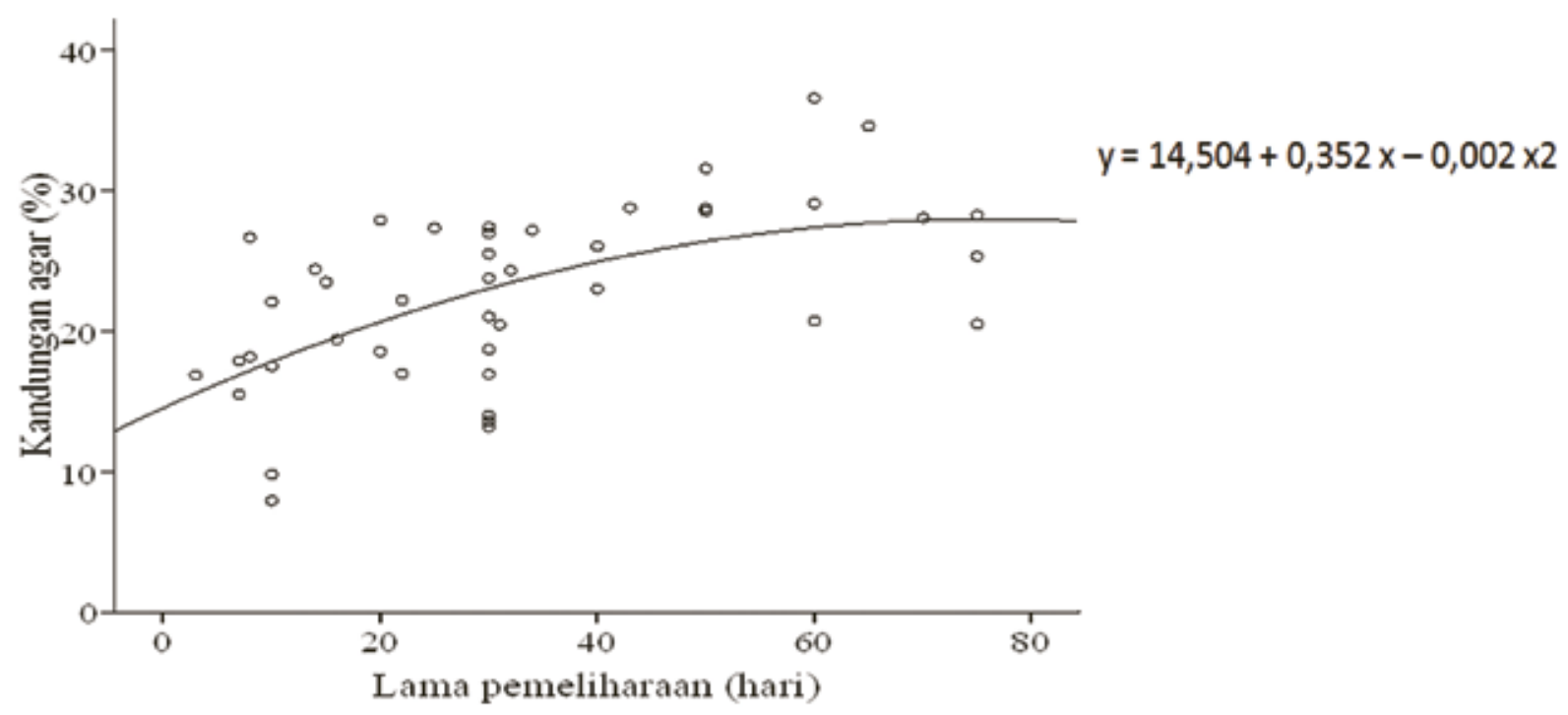

Gambar 9. Hubungan antara kandungan agar dan lama pemeliharaan rumput laut (Gracilaria verrucosa) di tambak Kabupaten Luwu Utara Provinsi Sulawesi Selatan

mengurangi melimpahnya klekap dan lumut, maka dapat ditebar ikan bandeng dengan padat penebaran 2.0003.000 ekor/ha sebagai sistem polikultur di tambak. Kedua komoditas tersebut menuntut kondisi lingkungan relatif sama tetapi menempati relung ekologi yang berbeda sehingga dapat dipolikulturkan di tambak.

Selama pemeliharaan dapat dilakukan pergantian air sekitar $60 \%$ pada setiap hari saat pasang tinggi. Pemupukan susulan juga dilakukan sesudah pergantian air terutama pupuk yang mengandung $\mathrm{P}$ seperti SP-36. Pemupukan susulan dengan pupuk yang mengandung nitrogen seperti urea dengan dosis yang lebih rendah pada musim hujan dibandingkan musim kemarau. Pengapuran susulan dengan kaptan dan dolomit perlu dilakukan terutama pada tambak-tambak yang pematangnya terbuka atau tidak tertutupi oleh rumput, terutama pada musim hujan untuk menetralisir kemasaman yang masuk ke dalam air tambak. Selama pemeliharaan, sebaiknya dilakukan pembersihan partikel lumpur yang melekat pada tubuh rumput laut, serta menyebarkan rumput laut secara merata di tambak. Panen pertama sebaiknya dilakukan setelah 2 bulan setelah penebaran dan selanjutnya setiap 45 hari. Pada lama pemeliharaan 45 hari persentase bobot kering rumput laut telah mencapai maksimum yaitu 20,4\% (Gambar 8). Kandungan agar rumput laut sebesar $30,3 \%$ sudah dapat diperoleh pada lama pemeliharaan 45 hari di tambak Kabupaten Lutra (Gambar 9). Kualitas rumput laut lainnya yang perlu diperhatikan adalah kandungan air sekitar 13\%-18\% dan keberadaan benda asing seperti garam, pasir, kayu, cangkang, dan lumut kurang dari 5\% setelah proses pengeringan.

\section{PENUTUP}

Sumberdaya lahan termasuk tanah di Kabupaten Luwu Utara (Lutra) Provinsi Sulawesi Selatan didominasi oleh tanah sulfat masam. Luas tambak di Kabupaten Lutra meningkat dari 4.938,84 ha pada tahun 2002 menjadi 7.838,94 ha pada tahun 2005. Potensi lahan tambak di Kabupaten Lutra mencapai 11.299,00 ha yang terdiri atas lahan tambak yang ada seluas 7.838,94 ha dan potensial lahan tambak seluas $3.460,06$ ha. Dari luas potensi lahan tambak di Kabupaten Lutra, ternyata $3.527,3$ ha tergolong sangat sesuai (kelas S1); 490,9 ha tergolong cukup sesuai (kelas S2); dan 7.280,8 ha tergolong kurang sesuai (kelas S3).

Untuk pemanfaatan tambak bagi budidaya rumput laut di Kabupaten Lutra diperlukan upaya perbaikan tanah melalui remediasi, serta pengeringan tanah pada saat persiapan tambak yang dilakukan pada awal musim kemarau sehingga penebaran rumput laut juga dapat dilakukan pada musim kemarau dengan kondisi air yang lebih baik. Penebaran rumput laut dengan bibit yang baik disarankan sebanyak 1.000-1.250 kg basah/ha yang dipolikultur dengan bandeng sekitar 2.000-3.000 ekor/ha. Panen sebaiknya dilakukan setelah lama pemeliharaan 45 hari. 


\section{DAFTAR ACUAN}

Anonim. 2003. Rumput laut Luwu terbaik di Indonesia. Fajar, Senin, 17 Maret 2003. hlm. 16.

Anonim. 2005. Laporan Statistik Perikanan Sulawesi Selatan 2002. Dinas Perikanan dan Kelautan Provinsi Sulawesi Selatan. Makassar, $261 \mathrm{hlm}$.

Boney, A.D. 1989. Phytoplankton. Second edition. Edward Arnold. London, $118 \mathrm{pp}$.

Boyd, C.E. 1990. Water quality in ponds for aquaculture. Birmingham Publishing Co. Birmingham, Alabama, 454 pp.

Caliceti, M., Argese, E., Sfriso, A., \& Pavoni, B. 2002. Heavy metal contamination in the seaweeds of the Venice lagoon. Chemosphere, 47: 443-454.

Departemen Kelautan dan Perikanan (DKP). 2005. Revitalisasi perikanan budidaya. Departemen Kelautan dan Perikanan. Jakarta, 275 hlm.

Effendi, H. 2003. Telaah kualitas air bagi pengelolaan sumber daya dan lingkungan perairan. Penerbit Kanisius. Yogyakarta, $258 \mathrm{hlm}$.

Gosavi, K., Sammut, J., Gifford, S., \& Jankowski, J. 2004. Macroalgal biomonitors of trace metal contamination in acid sulfate soil aquaculture ponds. Science of the Total Environment, 324(1-3): 25-39.

Hasnawi \& Mustafa, A. 2010. Karakteristik, kesesuaian, dan pengelolaan lahan untuk budidaya tambak di Kabupaten Luwu Utara Provinsi Sulawesi Selatan. J. Ris. Akuakultur, 5(3): 449-463.

Hurtado-Ponce, A.Q. \&Umezaki, I. 1987. Growth rate studies of Gracilaria verrucosa (Gigartinales, Rhodophyta). Botanica Marina, 30: 223-226.

Kaladharan, P., Vijayakumaran, K., \& Chennubhotla, V.S.K. 1996. Optimization of certain physical parameters the mariculture of Gracilaria edulis (Gmelin) Silva in Minicoy lagoon (Laccadive Archipelago). Aquaculture, 139: 165-270.

Liaw, W.K. 1969. Chemical and biological studies of fishponds and reservoirs in Taiwan. Rep. Fish Culture Res., Fish. Series, Chin. Am. Joint Commission on Rural Reconstruction, 7: 1-43.

Malea, P. \& Haritonidis, S. 1999. Metal content in Enteromorpha linza (Linnaeus) in Themaikos Gulf (Greece). Hydrobiologia, 394: 103-112.
Mira \& Reswati, E. 2006. Analisis daya saing usaha budidaya rumput laut di Indonesia. Jurnal Kebijakan dan Riset Sosial Ekonomi Kelautan dan Perikanan, 1(2): 165-173.

Moore, J.W. 1991. Inorganic contaminants of surface water. Springer-Verlag. New York, 334 pp.

Mubarak, H., Ilyas, S., Ismail, W., Wahyuni, I.S., Hartati, S.T., Pratiwi, E., Jangkaru, Z., \& Arifudin, R. 1990. Petunjuk teknis budidaya rumput laut. Pusat Penelitian dan Pengembangan Perikanan. Jakarta, $93 \mathrm{hlm}$.

Mustafa, A., Paena, M., Tarunamulia, \& Sammut, J. 2008. Hubungan antara faktor kondisi lingkungan dan produktivitas tambak untuk penajaman kriteria kesesuaian lahan. 2. Kualitas tanah. J. Ris. Akuakultur, 3(1): 105-121.

Mustafa, A. \& Ratnawati, E. 2005. Faktor pengelolaan yang berpengaruh terhadap produksi rumput laut (Gracilaria verrucosa) di tambak tanah sulfat masam (studi kasus di Kabupaten Luwu Provinsi Sulawesi Selatan). J. Pen. Perik. Indonesia, 11(7): 67-77.

Mustafa, A. \& Sammut, J. 2007. Effect of different remediation techniques and dosages of phosphorus fertilizer on soil quality and klekap production in acid sulfate soil-affected aquaculture ponds. Indonesian Aquaculture Journal, 2(2): 141-157.

Mustafa, A. \& Sammut, J. 2010. Dominant factors effecting seaweed (Gracilaria verrucosa) production in acid sulfate soils-affected ponds of Luwu Regency, Indonesia. Indonesian Aquaculture Journal, 5(2): 147-162.

Mustafa, A., Sapo, I., Hasnawi, \& Sammut, J. 2007. Hubungan antara faktor kondisi lingkungan dan produktivitas tambak untuk penajaman kriteria kelayakan lahan: 1. Kualitas air. J. Ris. Akuakultur, 2(3): 289-302.

Paena, M., Mustafa, A., Hasnawi, \& Rachmansyah. 2008. Validasi luas periodik dan penentuan luas potensi tambak di Kabupaten Luwu Utara Provinsi Sulawesi Selatan dengan menggunakan teknologi penginderaan jauh dan sistem informasi geografis. J. Ris. Akuakultur, 3(1): 137-146.

Ponnamperuma, F.N. 1976. Spesific soil chemical characteristics for rice production in Asia. IRRI Research Paper Seri No. 2. The International Rice Research Institute. Los Ba os, 18 pp. 
Ratnawati, E., Mustafa, A., \& Rachmansyah. 2008. Faktor status pembudidaya, kondisi dan pengelolaan tambak yang berpengaruh terhadap produksi rumput laut (Gracilaria verrucosa) di tambak tanah sulfat masam Kabupaten Luwu Utara Provinsi Sulawesi Selatan. J. Ris. Akuakultur, 3(2): 275-287.

Rorison, I.H. 1973. The effect of extreme soil acidity on the nutrient uptake and physiology of plant. In Dost, H. (Ed.) Proceedings of the International Symposium on Acid Sulphate Soils. ILRI Publication 18. International Institute for Land Reclamation and Improvement. Wageningen, p. 223-254.

Schaetzl, R.J. \& Anderson, S. 2005. Soils: Genesis and geomorphology. Cambridge University Press. Cambridge, 817 pp.
Sukadi, M.F. 2006. Perkembangan budidaya rumput laut di Indonesia. Dalam Cholik, F., Moeslim, S., Heruwati, E.S., Ahmad, T., \& Jauzi, A. (Eds.) 60 tahun Perikanan Indonesia. Masyarakat Perikanan Nusantara. Jakarta, hlm. 213-223.

Tseng, C.K. \& Borowitzka, M. 2003. Algae culture. In Lucas, J.S. \& Southgate, P.C. (Eds.), Aquaculture: Farming Aquatic Animals and Plants. Blackwell Publishing Ltd. Oxford, p. 253-275.

Yang, Y.-F., Fei, X.-G., Song, J.-M, Hu, H.-Y., Wang, G.-C., \& Chung, I.K. 2006. Growth of Gracilaria lemaneiformis under different cultivation conditions and its effects on nutrient removal in Chinese coastal waters. Aquaculture, 254: 248-255. 
